\title{
Correction to: Engineering of Biological Pathways: Complex Formation and Signal Transduction
}

\section{Philipp Junk and Christina Kiel}

\section{Correction to:}

Chapter 4 in: Irina S. Moreira et al. (eds.), Computational Design of Membrane Proteins: Methods and Protocols, Methods in Molecular Biology, vol. 2315, https://doi.org/10.1007/978-1-0716-1468-6_4

In the original version of this book, chapter 4 was published non-open access. It has now been changed to open access under a CC BY 4.0 license, and the copyright holder has been updated to "The Author(s)." This book has been updated with these changes.

The updated online version of this chapter can be found at https://doi.org/10.1007/978-1-0716-1468-6_4 